\title{
Spatio-temporal variation in number and production of neustonic and planktonic bacteria inhabiting polluted estuarine harbour channel
}

\author{
Piotr Perliński ${ }^{1}$ - Zbigniew J. Mudryk ${ }^{1} \cdot$ Marta Zdanowicz $^{1} \cdot$ Łukasz Kubera $^{2}$
}

Received: 6 May 2021 / Revised: 27 July 2021 / Accepted: 17 August 2021 / Published online: 25 August 2021

(c) The Author(s) 2021

\begin{abstract}
The aim of this paper was to determine the abundance and secondary production by bacteria inhabiting the surface microlayer and subsurface water in a specific water basin, i.e., polluted estuarine harbour channel. In a 3-year seasonal cycle, the total number of bacteria and their biomass were higher in the surface microlayer (SML) $7.57 \times 10^{8} \mathrm{cells} \mathrm{dm}^{-3}$ and $15.86 \mu \mathrm{g}$ $\mathrm{C} \mathrm{dm}^{-3}$ than in the subsurface water (SSW) $4.25 \times 10^{8} \mathrm{cells} \mathrm{dm}^{-3}$ and $9.11 \mu \mathrm{g} \mathrm{C} \mathrm{dm}{ }^{-3}$ of the studied channel. The opposite relationship was noted in the level of the secondary production ( $\mathrm{SML}-37.16 \mu \mathrm{g} \mathrm{C} \mathrm{dm}{ }^{-3} \mathrm{~h}^{-1}$, SSW $-60.26 \mu \mathrm{g} \mathrm{C} \mathrm{dm}^{-3} \mathrm{~h}^{-1}$ ) in this water basin. According to the analysed microbiological parameters, the total number of bacteria and secondary production varied along the horizontal profile in the water of the studied channel. The total number of bacteria and their secondary production showed the seasonal variation as well.
\end{abstract}

Keywords Harbour channel $\cdot$ Surface microlayer $\cdot$ Subsurface water $\cdot$ Total bacterial number $\cdot$ Bacterial production

\section{Introduction}

The surface microlayer (SML) is a boundary between the hydrosphere and atmosphere of a thickness varying from 10 to $250 \mu \mathrm{m}$, which chemical, physical, and biological properties differ from those of the subsurface water (SSW) (Chance et al. 2018; Zäncker et al. 2021). The SML is one of the largest and most important interface on our planet and it occupies approximately $70 \%$ of the Earth's surface, covering all marine, estuarine, and freshwater bodies (Astrahan et al. 2016; Engel et al. 2017). The SML is a gel-like proteinaceous hydrated elastic biofilm that is composed mainly of transparent exopolymer particles (Engel and Galgani

Communicated by Govarthanan Muthusamy.

Piotr Perliński

piotr.perlinski@apsl.edu.pl

1 Department of Experimental Biology, Institute of Biology and Earth Sciences, Pomeranian University in Słupsk, Arciszewskiego 22b, 76-200, Słupsk, Poland

2 Department of Microbiology and Immunobiology, Faculty of Biological Sciences, Kazimierz Wielki University, Al. Powstańców Wielkopolskich 10, 85-090 Bydgoszcz, Poland
2016; Dreshchinskii and Engel 2017). This boundary layer constitutes one of the most geochemically and biologically active areas of the biosphere (Ram et al. 2018). The SML is biochemical microreactor, which plays a key and unique role in the dynamic exchange of various gases, mainly $\mathrm{CO}_{2}$, and heat between the hydrosphere and atmosphere; it has potentially significant effects on climate change, regulation of biogeochemical cycles on global scale, precipitation, temperature changes, and controls the rates of exchange of energy and matter between water basins and air (Sabbaghzadeh et al. 2017; Wurl et al. 2017). Although the SML as a very dynamic structure is frequently disrupted by rain and wind of speed greater than 5-6 m s${ }^{-1}$ (Engel and Galgani 2016; Sun et al. 2018), the results of stirred tank experiments suggest that microlayers can self-reconstruct their original structure in less than a minute (Cunliffe et al. 2013). The surface microlayer is generally enriched in both dissolved and particulate organic matter by physical processes including diffusion, convection, advection, adhesion to rising bubble, upwelling of sub-surface water and particle deposition from air (Kurata et al. 2016; Perliński et al. 2017). Compared to subsurface waters, the surface microlayer can be enriched up to $10^{2}-10^{3}$ times in molecular and dissolved organic matter consisting mainly of proteins, carbohydrates, lipids, nucleic acids, chitin, pectin and cellulose (Perliński et al. 
2017). Such biogenic molecules have been shown to be major biochemical components of the SML (Galachyants et al. 2018; Shaharom et al. 2018). The primary sources of these organic compounds are phytoplankton and bacteria exudates, terrestrial organic matter transported from land, natural organic matter from the water column and bottom and various anthropogenic sources (Engel et al. 2017; Sabbaghzadeh et al. 2017). The enrichment of biogenic organic matter can render the SML to favourable habitat to development of microbial life (Zäncker et al. 2017). It is worth noting that apart from the factors positively influencing the number of microorganisms in the surface microlayer, we can also observe the influence of negative factors, such as temperature amplitude, solar radiation (particularly UV) and chemical toxic substances, as well as mortality by viruses and grazing (Antonowicz et al. 2017a). For example, a study conducted by Tovar-Sánchez et al. (2014) revealed that the SML of the Mediterranean Sea is enriched with bioactive trace metals ranging from 8 (for $\mathrm{Cd}$ ) to 1000 (for $\mathrm{Fe}$ ) times higher than the dissolved metal pool in the subsurface water.

Life in this unique ecotone is dominated by different microorganisms called neuston (Kostrzewska-Szlakowska and Kiersztyn 2017; Helm 2021). An extensive research has shown that the surface microlayer contains elevated number of heterotrophic and autotrophic microorganisms including mainly bacteria, cyanobacteria, flagellates, algae, and invertebrates (Santos et al. 2011; Astrahan et al. 2016). Among these neustonic organisms, bacterioneuston is dominant, for which the SML is considered favourable life habitat due to the accumulation of a large amount of organic matter (Kostrzewska-Szlakowska and Kiersztyn 2017; Antonowicz and Kozak 2020). This bacterial community plays a considerable role in maintaining the SML physicochemical properties, is actively involved in the exchange of substances and gases, mainly greenhouses gases, between the atmosphere and hydrosphere and is essential to the global organic matter cycle (Cunliffe et al. 2011; Kurata et al. 2016; Galachyants et al. 2018). According to Zwisler et al. (2003) and Franklin et al. (2005) to fully understand the role of bacterioneuston in the function of the surface microlayer, it is necessary not only to determine its enzymatic activity, physiological properties and taxonomic diversity of these organisms but also determine its abundance and level of the secondary production. Hence, during recent years, numerous studies on the number and productivity of bacterioneuston in freshwater (Kalwasińska and Donderski 2005; Zdanowicz and Mudryk 2017; Galachyants et al. 2018), estuarine (Mudryk and Skórczewski 2007; Santos et al. 2011; Azevedo et al. 2012), and marine environments (Stolle et al. 2010; Nakajima et al. 2013; Astrahan et al. 2016) were carried out. However, to our knowledge, no studies on the abundance of neustonic bacteria and their secondary production rate in a specific water reservoir such as an estuarine harbour channel are available so far. Therefore, the aim of this paper was to determine spatio-temporal heterogeneity in the abundance and level of carbon production by bacteria inhabiting the surface microlayer and subsurface water in the estuarine channel in the port Ustka (southern Baltic Sea).

\section{Materials and methods}

\section{Study area and sampling}

This study was carried out in the harbour channel (Fig. 1), which is the estuarine part of the Stupia River (Poland). The catchment area of the river covers $1623 \mathrm{~km}^{2}$ over $60 \%$ of that area is exploited mainly for agricultural purposes (Perliński et al. 2017). This river carries $15.5 \mathrm{~m}^{3} \mathrm{~s}^{-1}$ of water into the Baltic Sea, as well as 200,000-300,000 $\mathrm{m}^{3}$ year $^{-1}$ of natural and anthropogenic sediments (Zawadzka 1996). The studied channel is $1.1 \mathrm{~km}$ long, $40.5 \mathrm{~m}$ wide and about $6 \mathrm{~m}$ deep, and is located in the vicinity of the port in Ustka $\left(54^{\circ}\right.$ $35.2 \mathrm{~N}, 16^{\circ} 21.2 \mathrm{E}$ ) (Fig. 1). The studied harbour channel is limited by two breakwaters of about $300 \mathrm{~m}$ length, which are also the final part, where the Słupia River enters the sea (Perliński et al. 2017). The port in Ustka covers the area of $0.3 \mathrm{~km}^{2}$ and its main functions are fishery, marine transport, tourism, and shipbuilding (Christowa et al. 2007). All these economic activities bring a significant load of contamination, in particular, heavy metals, which concentration in the water of the port and coastal sea water in its region is presented in Table 1. At the same time, this harbour channel is the home port for 113 vessels. All these vessels (such as fishing boats, yachts and passenger ships) are the sources of petroleum hydrocarbon pollution, which concentration in the years 2005-2017 varied in the range of $<0.1$ to $1.45 \mathrm{~g} \mathrm{~m}^{-3}$ according to the Maritime Office in Stupsk.

Selected chemical and microbiological parameters of the water in the harbour channel are presented in Table 2.

The water samples from the channel in Ustka were collected at four sites (Fig. 1).

Site 1-located on the border between the Slupia River and the studied channel.

Site 2-placed in the central part of the channel.

Site 3-located in one of the water basins called the coal basin.

Site 4-located at the site, where the estuarine channel enters the sea, i.e., near the heads of breakwaters.

The precise location of each sampling site was taken with a GPS receiver installed on the board of the tugboat (Fig. 1). The water samples were collected quarterly in autumn (a), winter (w), spring (sp), and summer (s) during 2010-2013. The surface microlayer (SML) samples (thickness $150-250 \mu \mathrm{m}$ ) were collected with a $75 \times 75 \mathrm{~cm}$ metal screen according to the method of Garrett (Garrett 1965). 


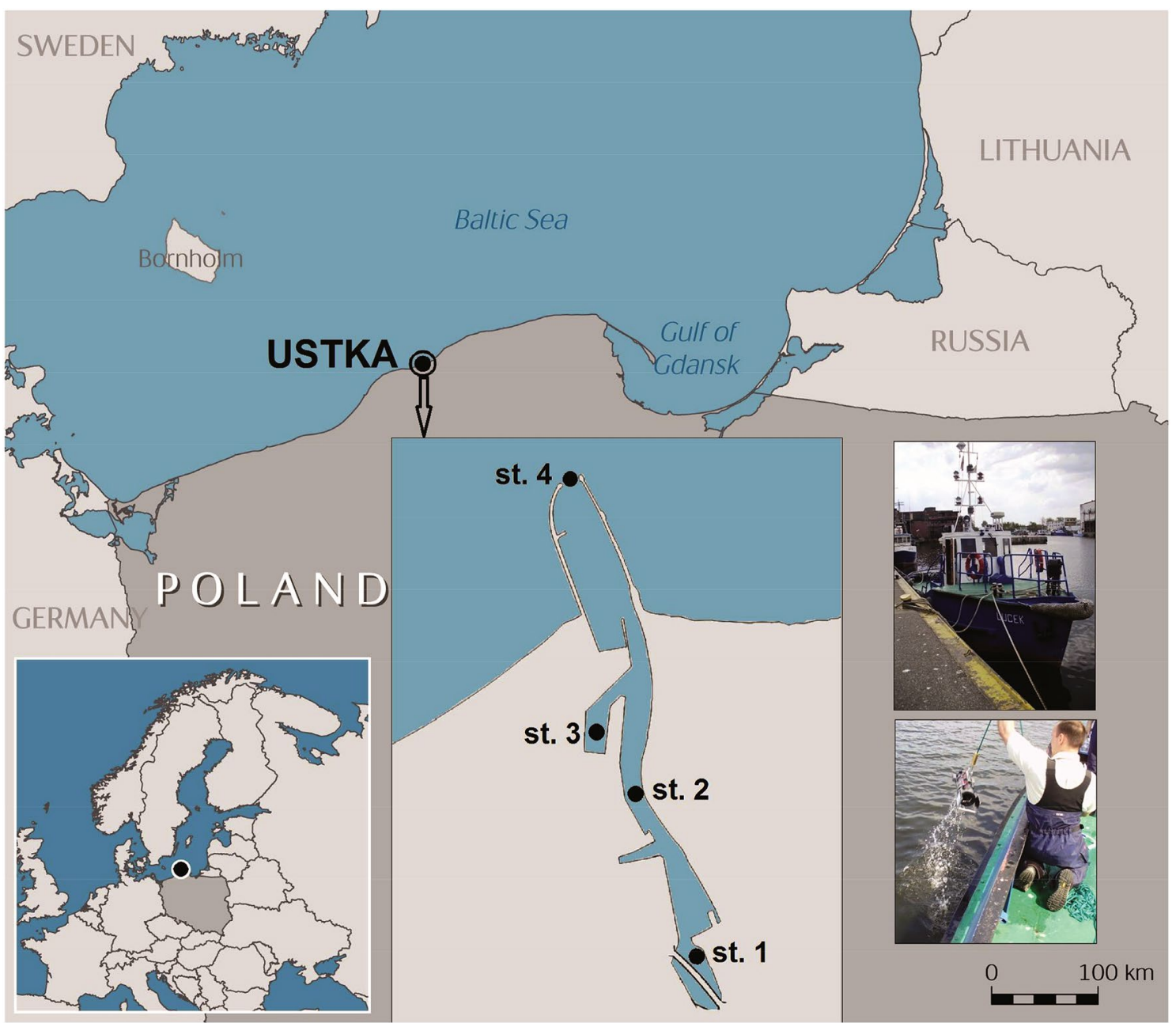

Fig. 1 Map of localization the study estuarine harbour channel and sampling sites in Ustka

Table 1 Mean concentrations of heavy metals and arsenic and standard deviations recorded in surface waters of the Harbour and coastal sea waters (Antonowicz et al. 2017b)

\begin{tabular}{llllll}
\hline \multirow{2}{*}{$\begin{array}{l}\text { Chemical param- } \\
\text { eters }\end{array}$} & \multicolumn{2}{l}{ Harbour } & & \multicolumn{2}{l}{ Coastal sea waters } \\
\cline { 2 - 3 } \cline { 5 - 6 } & Mean & $\mathrm{SD}$ & & Mean & $\mathrm{SD}$ \\
& \multicolumn{2}{l}{ Concentration $\left(\mu \mathrm{g} \mathrm{dm}^{-3}\right)$} & & \\
\hline $\mathrm{Mn}$ & 2.66 & 1.09 & 3.07 & 2.16 \\
$\mathrm{Ni}$ & 4.50 & 4.08 & 10.93 & 2.87 \\
$\mathrm{Cu}$ & 3.56 & 2.89 & 5.5 & 2.43 \\
$\mathrm{Zn}$ & $<20$ & - & $<20$ & - \\
$\mathrm{Cd}$ & 0.14 & 0.81 & 0.21 & 0.08 \\
$\mathrm{~Pb}$ & $<5$ & - & $<5$ & - \\
$\mathrm{As}$ & 0.41 & 0.38 & 0.62 & 0.71 \\
\hline
\end{tabular}

The mesh size of the metal screen was $0.14 \mathrm{~mm}$. The water collected with the Garrett net was scrapped off with the wiper and then transferred to a sterile bottle. The subsurface water (SSW) was collected at about $0.5 \mathrm{~m}$ depth with a horizontal van Dorn water sampler adapted for the collection of the samples in flowing water (Fig. 1) (Perliński et al. 2017). The collected water samples were transferred to sterile bottles using drain valve. Prior to sampling, the Garret net and van Dorn sampler were rinsed several times with distilled sterile water and $80 \%$ ethyl alcohol. The collected samples of water were transported to the laboratory in the ice containers at the temperature that did not exceed $7{ }^{\circ} \mathrm{C}$.

\section{Determination total bacteria number and biomass}

The total bacterial number (TBN) was established with the DAPI (4,6-diamidino-2-phenyl-indol) direct method according to Porter and Feig (1980). Aliquots of $10 \mathrm{~cm}^{3}$ were preserved with formaldehyde at final concentration of $1 \%$. A solution of DAPI $\geq 98 \%$ (Fluka) at a concentration of $50 \mu \mathrm{g} \mathrm{cm}$ was added to $1 \mathrm{~cm}^{3}$ of the fixed water sample. After mixing the sample on a shaker, it was placed in the 
Table 2 Values of selected chemical and microbiological parameters in the harbour channel (Perliński 2015)

\begin{tabular}{|c|c|c|c|c|c|c|c|c|c|}
\hline \multirow[t]{2}{*}{ Parameters } & \multirow[t]{2}{*}{ Units } & \multicolumn{2}{|l|}{ st.1 } & \multicolumn{2}{|l|}{ st.2 } & \multicolumn{2}{|l|}{ st. 3} & \multicolumn{2}{|l|}{ st. 4} \\
\hline & & Mean & Range & Mean & Range & Mean & Range & Mean & Range \\
\hline $\mathrm{N}-\mathrm{NO}_{3}$ & $\mathrm{mg} \mathrm{dm}^{-3}$ & 7.26 & $1.37-15.98$ & 8.49 & $3.65-15.66$ & 13.56 & $3.9-48.43$ & 11.68 & $4.16-22.3$ \\
\hline $\mathrm{N}-\mathrm{NH}_{4}$ & $\mathrm{mg} \mathrm{dm} \mathrm{m}^{-3}$ & 48.45 & $26.06-103.23$ & 50.39 & $25.27-136.43$ & 43.82 & $22.4-100.25$ & 45.93 & $21.97-106.63$ \\
\hline $\mathrm{Cl}^{-}$ & $\mathrm{mg} \mathrm{dm}^{-3}$ & 294.28 & $36.46-741.40$ & 419.57 & $94.58-1250.28$ & 574.87 & $128.88-1306.12$ & 1852.13 & $381.92-5909.11$ \\
\hline $\mathrm{O}_{2}$ & $\mathrm{mg} \mathrm{dm} \mathrm{m}^{-3}$ & 7.05 & $4.76-10.42$ & 7.44 & $4.17-11.11$ & 6.81 & $5.63-7.61$ & 7.06 & $5.21-9.13$ \\
\hline $\mathrm{pH}$ & & 7.28 & $6.80-7.70$ & 7.27 & $6.53-7.70$ & 7.45 & $7.09-7.70$ & 7.45 & $7.18-7.67$ \\
\hline $\mathrm{OM}$ & $\mathrm{mg} \mathrm{dm}^{-3}$ & 0.45 & $0.30-0.70$ & 0.79 & $0.30-1.70$ & 0.68 & $0.40-0.90$ & 0.89 & $0.20-2.30$ \\
\hline Protein & $\mu \mathrm{g} \mathrm{dm}{ }^{-3}$ & 23.81 & $15.12-34.32$ & 22.10 & $16.31-28.01$ & 21.01 & $15.31-27.42$ & 22.99 & $17.31-29.87$ \\
\hline Lipids & $\mu \mathrm{g} \mathrm{dm}^{-3}$ & 109.21 & $43.88-222.57$ & 85.21 & $36.27-175.54$ & 105.04 & $24.38-248.46$ & 360.57 & $20.09-888.59$ \\
\hline Carbohydrates & $\mu \mathrm{g} \mathrm{dm}^{-3}$ & 72.31 & $31.27-135.11$ & 75.46 & $21.87-154.96$ & 60.74 & $32.03-91.13$ & 47.33 & $24.36-70.55$ \\
\hline $\begin{array}{l}\text { Number of heterotrophic } \\
\text { bacteria }\end{array}$ & $10^{6} \mathrm{dm}^{-3}$ & 23.30 & $3.17-91.67$ & 23.40 & $2.33-79.18$ & 24.50 & $4.00-79.18$ & 19.17 & $1.50-62.27$ \\
\hline $\begin{array}{l}\text { Heterotrophic bacterial } \\
\text { biomass }\end{array}$ & $\mathrm{mg} \mathrm{dm} \mathrm{m}^{-3}$ & 37.41 & $5.07-146.67$ & 37.44 & $3.73-126.67$ & 39.20 & $6.40-126.67$ & 30.68 & $2.40-100.27$ \\
\hline
\end{tabular}

dark for 10-15 min to stain bacterial cells. Next using a Millipore filtration apparatus stained samples were filtrated with black - stained polycarbonate filters (Millipore) $(0.2 \mu \mathrm{m}$ pore size, $13 \mathrm{~mm}$ diameter). After filtering the sample, the filters were rinsed with $1 \mathrm{~cm}^{3}$ of $80 \%$ ethyl alcohol and then with $2 \mathrm{~cm}^{3}$ of double-distilled water. Counting bacteria absorbed on the filters were performed at $1000 \times$ magnification using OLYMPUS BX-41 epifluorescence microscope (equipped with an excitatory-barrier block UV-2A-excitation $\lambda=365 \mathrm{~nm}$, emission $\lambda=420 \mathrm{~nm}$ ) coupled with a Colour View III camera. Bacteria stained in blue were counted in 20 different fields with a minimum of 200 cells. TBN was calculated according to the formula proposed by Zimmermann and Meyer-Reil (1974). Bacterial cell numbers were transformed to bacterial biomass (BB) using the conversion factor $20 \mathrm{fg} \mathrm{C}$ cell $^{-1}$ (Lee and Fuhrman 1987; Chróst et al. 2000).

\section{Estimated bacterial production}

The secondary production of bacteria (BP) in the water samples was determined by measuring the rate of incorporation of methyl- $\left[{ }^{3} \mathrm{H}\right]$ thymidine $\left(\left[{ }^{3} \mathrm{H}\right] \mathrm{TdR}\right)$ into the bacterial DNA (Fuhrman and Azam 1982; Mudryk and Skórczewski 2007). To determine this parameter, $20 \mu \mathrm{l}\left[{ }^{3} \mathrm{H}\right] \mathrm{TdR}$ (NEN Life Science Products $60 \mathrm{Ci} \mathrm{nmol}^{-1}$ specific activity) was added to $10 \mathrm{~cm}^{3}$ water samples in three replications with final concentration of $20 \mathrm{nM} \mathrm{dm}{ }^{-3}$ and the samples were incubated for $60 \mathrm{~min}$ at $20^{\circ} \mathrm{C}$. After this time, the incubation was stopped by adding $200 \mu \mathrm{l}$ of $37 \%$ formaldehyde to the samples. A prekilled sample was used as a blank. The samples were then filtered with a Millipore sampling manifold on $0.22 \mu \mathrm{m}$ nitrate cellulose filters (Millipore, $25 \mathrm{~mm}$ diameter). The filters were rinsed twice with $5 \mathrm{~cm}^{3} 10 \%$ ice-cold
TCA and then dissolved in $1 \mathrm{~cm}^{3}$ of ethyl acetate and placed in scintillation vials (Packard) with $10 \mathrm{~cm}^{3}$ LCS-cocktail (Packard, Filter-Count). After 24 h, the samples were radioassayed in a Packard TRI-CRAB 2100TR liquid scintillation counter. The calculation of bacterial production was based on thymidine incorporation (TdR) using a factor of $1.25 \times 10^{9}$ cells nmol $^{-1}$ thymidine (Chróst et al. 1988). The bacterial growth rates $(\mu)$ were estimated by dividing bacte-

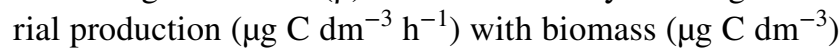
following Grossman and Dieckmann (1994), and Nakajima et al. (2013).

\section{Statistical analysis}

Standard statistics of data variation and dispersion (standard deviation-SD, coefficient of variation- $\mathrm{CV}$, coefficient of dispersion-CD) were calculated based on Velji and Albright (1986).

Enrichment or depletion of the studied bacterial parameters in the SML and SSW was estimated by calculating the average enrichment factor $(\mathrm{EF}) . \mathrm{EF}=x(\mathrm{SML}) / x(\mathrm{SSW})$, where " $x$ " was the value of a given bacteriological parameter in the SML or SSW, respectively. EF value $>1.0$ is defined as enrichment, while EF value $<1.0$ as depletion (Engel et al. 2017).

Following Incera et al. (2003), the significance of difference between the studied bacterial parameters among the layers, sites and seasons was assessed by a two-way ANOVA of variance and the Kruskal-Wallis test, non-parametric equivalent of ANOVA, when the data distribution differed from a normal distribution.

Simple linear regressions were carried out to determine the relationship between the total bacterial number and 
bacterial production in the surface microlayer and subsurface water (Zdanowicz and Mudryk 2017).

\section{Results}

The total number of bacteria (TBN), their biomass (BB), bacterial secondary production (BP), and bacterial growth rate $(\mu)$ in a 3-year seasonal cycle in the water of the studied channel are presented in Table 3. The analysis of these data showed that the total number of bacteria in the studied water layers varied in different years from 0.18 to 14.72 cells $\times$ $10^{8} \mathrm{dm}^{-3}$ with the mean value of 5.91 cells $\times 10^{8} \mathrm{dm}^{-3}$, while their biomass changed from 2.86 to $29.44 \mu \mathrm{g} \mathrm{C} \mathrm{dm}^{-3}$ with the mean value of $12.48 \mu \mathrm{g} \mathrm{C} \mathrm{dm}^{-3}$. The bacterial secondary production (BP) estimated from the rate of thymidine incorporation in the bacterial DNA in the studied channel varied from 0.86 to $222.00 \mu \mathrm{g} \mathrm{C} \mathrm{dm}^{-3} \mathrm{~h}^{-1}$ (mean $48.71 \mu \mathrm{g} \mathrm{C} \mathrm{dm}^{-3} \mathrm{~h}^{-1}$ ) and the bacterial growth rate changed within the range 0.04-32.71 day ${ }^{-1}$ (mean 4.9 day $^{-1}$ ). Data presented in Table 3 show that the total number of bacteria and their biomass enrichment factor were higher $\left(\mathrm{EF}_{\mathrm{TBN}, \mathrm{BB}}=1.7-1.8\right)$ in the surface microlayer (SML) than in the subsurface water (SWW). In contrast, the rate of secondary production of bacteria and bacterial growth rates was higher $\left(\mathrm{EF}_{\mathrm{BP}, \mu}=0.4-0.6\right)$ in the subsurface water compared to the surface microlayer.

The results of the present study indicated the difference in the total number of bacteria and secondary production along the horizontal profile in the water of the studied channel (Fig. 2). The highest total number of bacteria was noted on the border between the Slupia River and the studied channel (st.1) $\left(7.23\right.$ cells $\left.\times 10^{8} \mathrm{dm}^{-3}\right)$, while in the remaining sites, it was much lower and at a similar level (5.68-6.26 cells $\left.\times 10^{8} \mathrm{dm}^{-3}\right)$. The bacterial secondary production also varied between the zones of the harbour channel in Ustka. The level $\left(22.95 \mu \mathrm{g} \mathrm{C} \times \mathrm{dm}^{-3}\right)$ of secondary production of bacteria at the site located where the channel enters the sea (st.4) was two to three times lower than at other sites (54.28-60.89 $\mu \mathrm{g} \mathrm{C} \times \mathrm{dm}^{-3}$ ).
The total number of bacteria in the surface microlayer and subsurface water layers changed with the seasons. Data presented in Fig. 3 show that in a three-year seasonal cycle, the maximum values of the TBN in the surface microlayer $\left(11.40\right.$ cells $\left.\times 10^{8} \mathrm{dm}^{-3}\right)$ and subsurface layers $(6.88$ cells $\times 10^{8} \mathrm{dm}^{-3}$ ) were recorded in summer. The minimum numbers $\left(4.80\right.$ cells $\left.\times 10^{8} \mathrm{dm}^{-3}\right)$ of bacterioneuston were noted in autumn and of bacterioplankton in winter $(2.13$ cells $\times 10^{8} \mathrm{dm}^{-3}$ ). Large fluctuations of the seasonal dynamics of the level of bacterial production were also documented in the studied water layers (Fig. 3). In the surface microlayer $\left(164.82 \mu \mathrm{g} \mathrm{C} \mathrm{dm}{ }^{-3} \mathrm{~h}^{-1}\right)$ and subsurface water $\left(138.20 \mu \mathrm{g} \mathrm{C} \mathrm{dm}^{-3} \mathrm{~h}^{-1}\right)$, the maximum level of carbon production by bacteria was noted in the spring and summer seasons. The minimum rate of the secondary production of bacterioneuston $\left(7.16 \mu \mathrm{g} \mathrm{C} \mathrm{dm}{ }^{-3} \mathrm{~h}^{-1}\right)$ and bacterioplankton (15.14 $\mu \mathrm{g} \mathrm{C} \mathrm{dm}^{-3} \mathrm{~h}^{-1}$ ) was recorded in winter.

Linear regression showed that there was no significant relationship between the TBN and TB in the surface water. The highest correlation $\left(R^{2}=0.077, p<0.05\right)$ was found between the TBN and BP in the subsurface water (Fig. 4).

The obtained results were grouped by the seasons, layers and sites, and a two-way factorial ANOVA test was carried out for the total bacterial number and bacterial production (Table 4). The analyses showed significant differences in the total bacterial number among the layers and seasons, while there were no significant differences among the sites. The bacterial productivity rates were high $(p<0.001)$ and significantly differ $(p<0.05)$ between the seasons and layers, while the difference between the sites was low.

\section{Discussion}

Bacteria play a major role in functioning of aquatic ecosystems by actively participating in metabolic conversions of various forms of organic matter, recycling of nutrients and energy flux (Yucel 2017; Figueroa et al. 2021). Hence, the basic parameters used to describe the structure and metabolic activity of bacteriocenosis in all water basins are the total number and productivity of bacteria (Ameryk et al.
Table 3 Total number bacteria, biomass bacteria, bacterial production and bacterial growth rates in studied harbour channel (average data from three years of research)

\begin{tabular}{llrlrrrr}
\hline Bacterial parameters & Layer & Mean & Range & SD & CV [\%] & CD & EF \\
\hline Total bacterial number $\left[10^{8} \mathrm{dm}^{-3}\right]$ & SML & 7.57 & $0.43-14.72$ & 3.39 & 44.75 & 1.52 & 1.8 \\
& SSW & 4.25 & $0.18-8.96$ & 2.08 & 48.86 & 1.01 & \\
Bacterial biomass $\left[\mu \mathrm{g} \mathrm{C} \mathrm{dm}{ }^{-3}\right]$ & SML & 15.86 & $6.80-29.44$ & 3.59 & 22.6 & 0.81 & 1.7 \\
& SSW & 9.11 & $2.86-17.91$ & 4.88 & 53.5 & 2.61 & \\
Bacterial production $\left[\mu \mathrm{g} \mathrm{C} \mathrm{dm}^{-3} \mathrm{~h}^{-1}\right]$ & $\mathrm{SML}$ & 37.16 & $0.86-205.51$ & 50.83 & 136.8 & 69.51 & 0.6 \\
& $\mathrm{SSW}$ & 60.26 & $7.58-222.00$ & 53.59 & 88.9 & 47.65 & \\
Bacterial growth rate $(\mu)\left[\mathrm{day}^{-1}\right]$ & $\mathrm{SML}$ & 2.55 & $0.04-13.29$ & 3.56 & 139.48 & 4.96 & 0.4 \\
& $\mathrm{SSW}$ & 7.25 & $0.68-32.71$ & 5.30 & 73.13 & 3.88 & \\
\hline
\end{tabular}


Fig. 2 Horizontal variations of total bacterial number and production in studied channel (average from the pooled data of both water layers and all seasons). Vertical bars represent standard errors of the mean

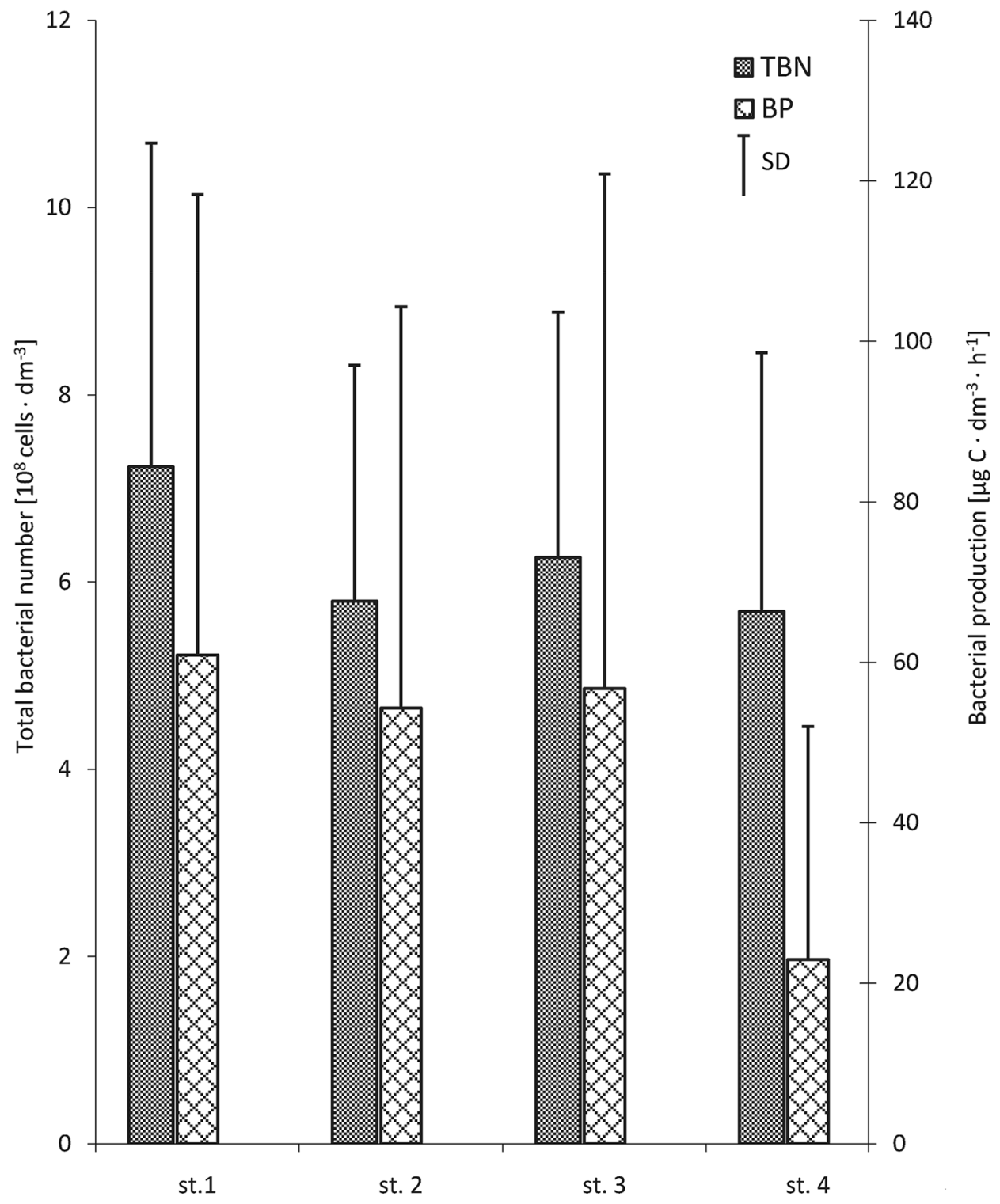

2005; Kostrzewska-Szlakowska and Kiersztyn 2017). This parameter is essential in our understanding of their ecological role and their contribution to marine processes.

The total bacterial number in Ria de Averio, a tidal lagoon (western coast of Portugal), varied from 0.2 to $8.5 \times 10^{9}$ cells $\mathrm{dm}^{-3}$ (Almeida et al. 2001), while in Kiel Bight (Baltic Sea), it was $2.8 \times 10^{9}$ cells dm $^{-3}$ (Mock et al. 1997). Much lower total bacterial number $\left(0.43-14.72 \times 10^{8}\right.$ cells dm$\left.^{-3}\right)$ was documented in the water of the studied harbour channel in Ustka. This low number of bacteria probably results from pollution of this water basin with heavy metals and petroleum hydrocarbon pollutants. This hypothesis is confirmed by Ma et al. (2015) and Xu et al. (2018).

An important mechanism for the transformation of organic matter accumulated in water bodies is the secondary production of bacteria (Steinberg et al. 2008; Santos et al. 2013). The calculation of this parameter enables estimation of the amount of organic matter transferred between the different links in the trophic chain in aquatic ecosystems (Hyun and Kim 2003; Lemée et al., 2002). In the water of the studied estuarine harbour channel, the secondary production of bacteria varied from 37.16 to $60.26 \mu \mathrm{g} \mathrm{C} \mathrm{dm}^{-3} \mathrm{~h}^{-1}$. This was higher than in the Ria de Averio tidal lagoon $\left(0.05-4.5 \mu \mathrm{g} \mathrm{C} \mathrm{dm}^{-3} \mathrm{~h}^{-1}\right.$ ) (Almeida et al. 2001), in the Scheldt estuary (0.3-11.5 $\mu \mathrm{g} \mathrm{C} \mathrm{dm}^{-3} \mathrm{~h}^{-1}$; Goosen et al. 1995), and in the Baltic Sea (Kiel Bight) (0.021-0.235 $\mu \mathrm{g} \mathrm{C} \mathrm{dm}^{-3} \mathrm{~h}^{-1}$; Mock et al. 1997). While, the level of bacterial secondary production in the channel in Ustka was significantly lower than those reported by $\mathrm{La}$ Ferla et al. (2005) in the Central Mediterranean Sea.

The results of the present study on the total number of bacteria inhabiting analysed water layers in the estuarine 

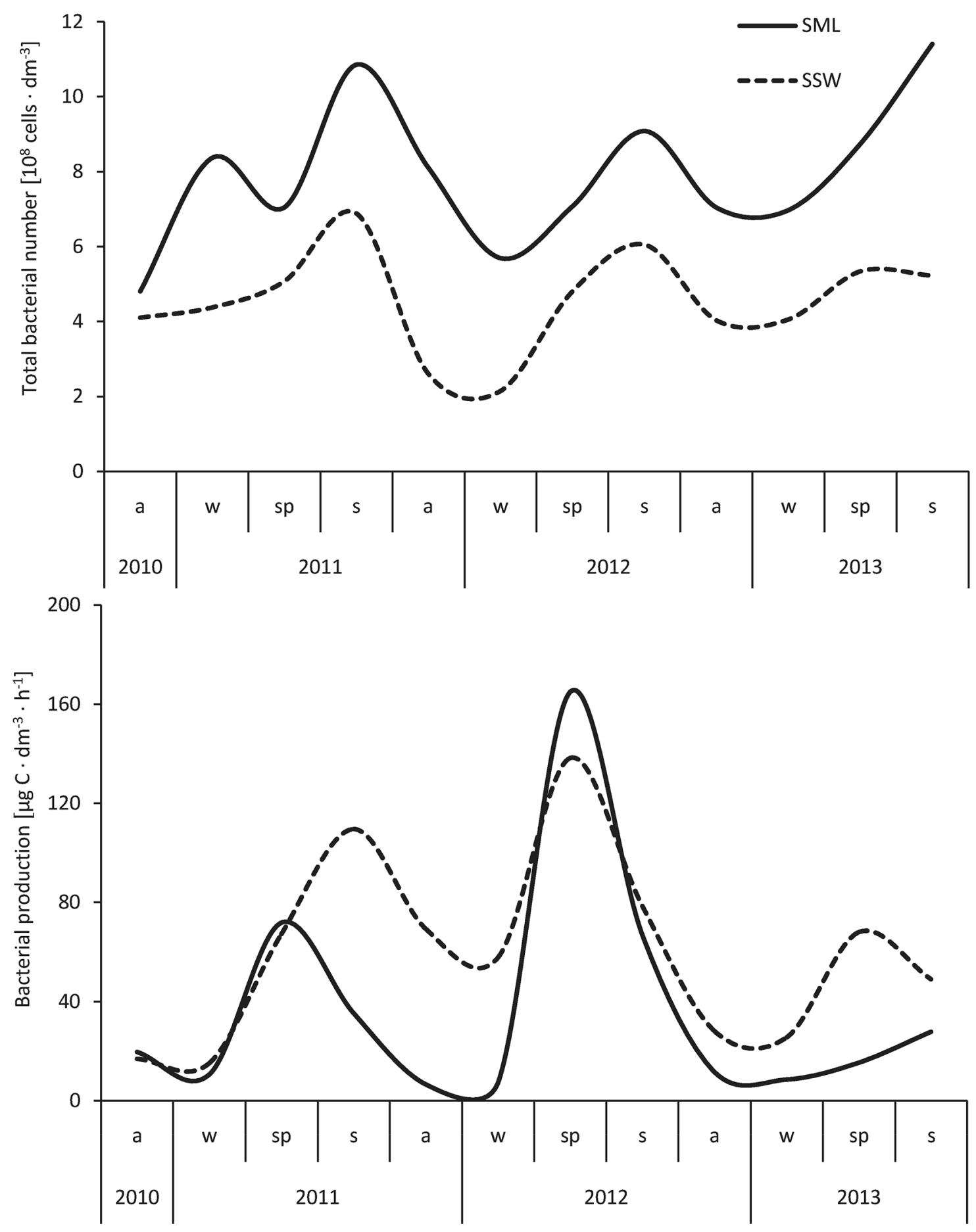

Fig. 3 Seasonal dynamics change of total bacteria number and bacterial production in surface microlayer and subsurface water in channel in Ustka (average from the pooled data of all sites)

harbour channel in Ustka showed that this parameter was almost two-fold higher in the surface microlayer $(7.57 \times$ $10^{8}$ cells $\left.\mathrm{dm}^{-3}\right)$ than in the subsurface water $\left(4.25 \times 10^{8}\right.$ cells $\mathrm{dm}^{-3}$ ). The same pattern was also documented by the studies on bacterioneuston and bacterioplankton abundance in inland reservoirs (Zdanowicz and Mudryk 2017; Galachyants et al. 2018), estuaries (Santos et al. 2009, Azevedo et al. 2012), and marine environment (Nakajima et al. 2013; Fan et al. 2018). Many abiotic and biotic factors influence such numerous occurrence of bacteria in the surface microlayer. 
Fig. 4 Relationship between total bacteria number (TBN) and level bacterial production (BP) in surface microlayer (SML) and subsurface water (SSW) in harbour channel. Solid lines represent linear regression including all data $(y$-regression equation $R^{2}$-coefficient of determination, $n$ number samples, $p$ significant level)

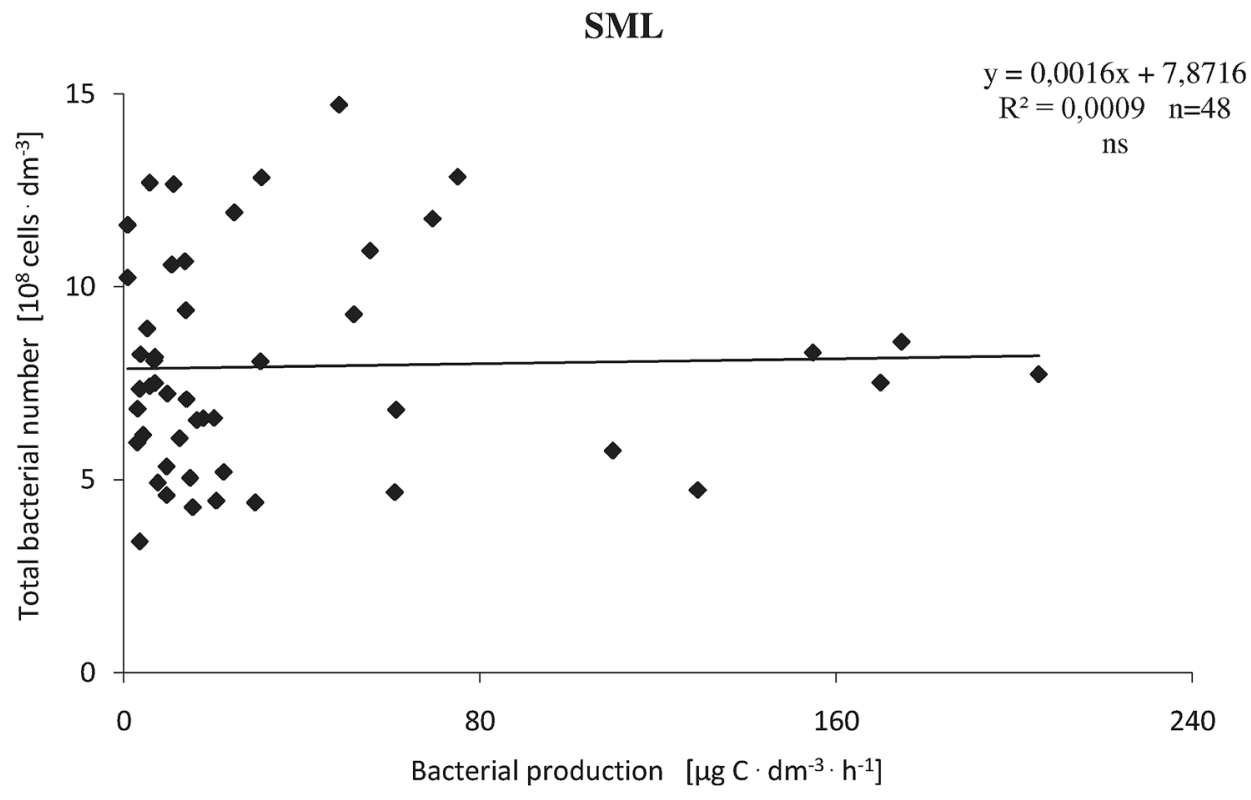

SSW

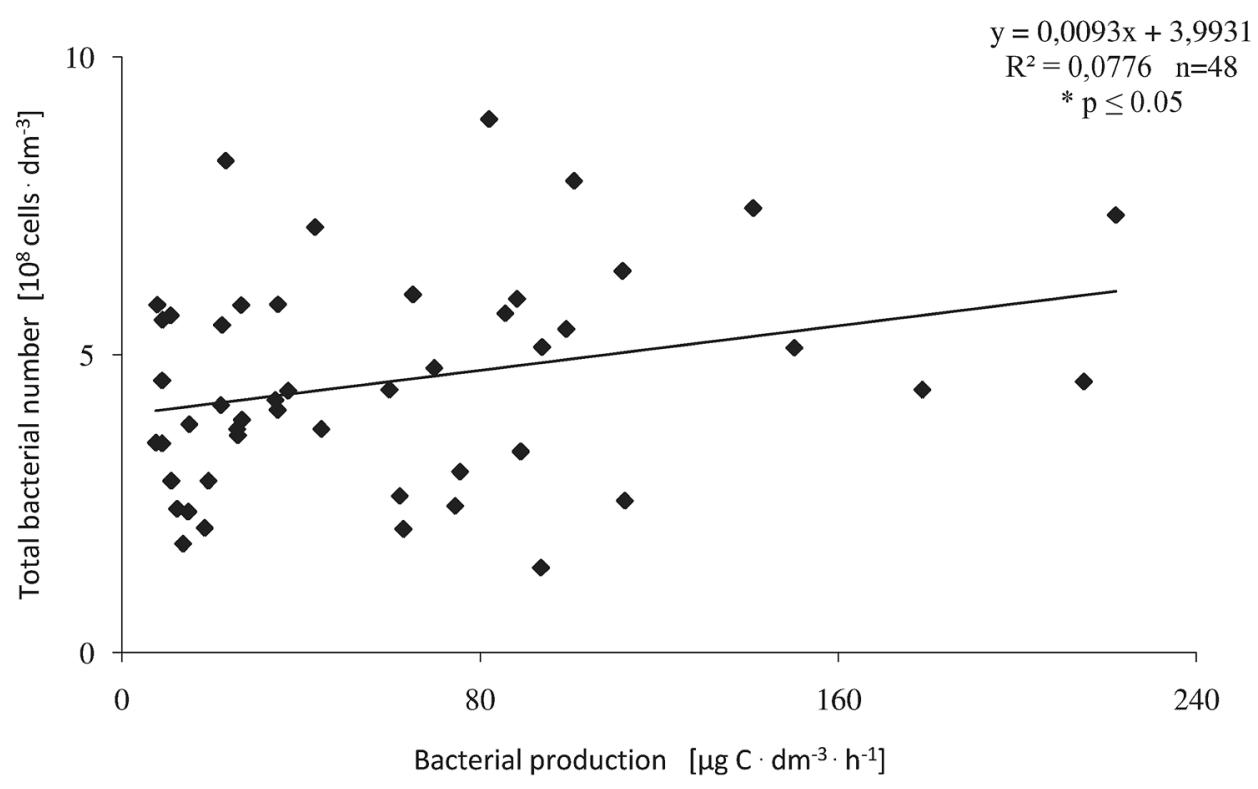

The accumulation of significant amounts of organic compounds potentially bioavailable for consumption by live organisms in the surface membrane stimulates optimal conditions for the development of bacterial microflora (Cunliffe et al. 2013; Astrahan et al. 2016). Also, an important driving force generating large amounts of bacterioneuston in the air-water boundary layer are excretions and secretions of phyto- and zooneuston consisting mainly of carbohydrates, proteins, and lipids (Wurl and Obbard 2004). These compounds are very actively assimilated by neuston bacteria as food substrates used to build cellular structures and as energy material necessary for metabolic processes (Santos et al. 2011; Astrahan et al. 2016). Another factor increasing the number of bacteria in the surface microlayer is the presence of specific extracellular structures in neustonic organisms. These are hydrophobic compounds (mucopolysaccharides, glycoproteins, phosphocholine lecithin), which significantly facilitate the adhesion of neuston bacteria to the surface microlayer (Walczak and Donderski 2005; Zdanowicz and Mudryk 2017). At the same time, many planktonic and benthic bacteria with the ability to move may migrate from deeper layers of water and bottom sediments to the surface microlayer by chemotaxis, flotation, adhesion to rising bubbles and buoyant particles (Stolle et al. 2010; Nakajima et al. 2013). Hervas and Casamayor (2008) also point out that the surface microlayer may also be enriched 
Table 4 Analyses of two-way-ANOVA rang Kruskal-Willis of variance in the studied taxonomic groups, due to site, layer and season

\begin{tabular}{llcl}
\hline Parameters & Source of variation & $H$ & $p$ \\
\hline TBN & Site & 3.163 & $\mathrm{~ns}$ \\
& Layer & 35.273 & $* * *$ \\
& Season & 17.495 & $* * *$ \\
& Site $\times$ layer & 39.559 & $* * *$ \\
& Site $\times$ season & 26.060 & $* *$ \\
& Layer $\times$ season & 53.208 & $* * *$ \\
BP & Site & 10.739 & $* *$ \\
& Layer & 11.861 & $* * *$ \\
& Season & 22.625 & $* * *$ \\
& Site $\times$ layer & 29.524 & $* * *$ \\
& Site $\times$ season & 37.783 & $* * *$ \\
& Layer $\times$ season & 36.949 & $* * *$ \\
\hline
\end{tabular}

$n s$ non significant, $H$ the Kruskal-Wallis test, $p$ significance level Significance $(p)$ is indicated by asterisks $* p<0.05, * * * p<0.001$

with bacteria by solid and liquid atmospheric precipitation. According to Antonowicz et al. (2015) and Zdanowicz, and Mudryk (2017), a very good oxygenation of this water layer also provides aerobic bacterioneuston with optimal development conditions.

Our research on the level of bacterial secondary production in the surface microlayer and subsurface water in the studied channel showed that the higher level of bacterial carbon production $(\mathrm{EF}=0.6)$ was found in the subsurface water. According to Zdanowicz and Mudryk (2017), these results indicate that planktonic bacteria are characterized by higher metabolic activity than neustonic bacteria due to their short generation time and high rate of cellular carbon production. Also, previous studies (Kalwasinska and Donderski 2005; Obernosterer et al. 2008; Santos et al. 2014; Antonowicz et al. 2015) documented that the production of bacterioplankton was higher than that of bacterioneuston. Stolle et al. (2009) and Zàncker et al. (2017) reported that thymidine incorporation by bacterioneuston in the Baltic Sea and Pacific Ocean was reduced by $5-80 \%$ compared to bacterioplankton. The results of the study by Obernosterer et al. (2008) allowed to estimate the fraction of active bacterial cells for roughly $10 \%$ and $25 \%$ of DAPI-stained cells in the surface microlayer, respectively.

Low bacterial productivity at the surface microlayer indicates that the air-water interface is a stressful environment for bacteria (Stolle et al. 2009; Santos et al. 2014). According to Kalwaśińska and Donderski (2005) and Obernosterer et al. (2008), low bacterial productivity at the SML is probably caused by the stressogenic effect of environmental factors, mainly drastic changes in temperature, $\mathrm{pH}$, salinity conditions and relatively high accumulation of heavy metals, biophenol, polyvinyl chloride, and pesticides. Those strong toxic compounds are frequently found in the SML in the quantity exceeding concentrations, which are safe for proper functioning of organisms inhabiting the surface microlayer, mainly bacteria algae and fungi (Antonowicz et al. 2017a). This thesis was confirmed by the studies of van Westernhagen et al. (1987) and Wurl and Obbard (2004) indicating that the concentrations of heavy metals in the surface microlayer were 100 times and toxic substances 500 times higher than in the subsurface water layers. The decrease in the level of bacterial production in the SML might be also caused naturally when bacterioneuston is exposed to high levels of solar radiation including the UV spectrum (Zàncker et al. 2017). Ultraviolet may cause photo-damage to cells by catalysing the intracellular formation of chemical intermediates, such as reactive oxygen species (ROS) and DNA photoproducts (Santos et al. 2014; Astrahan et al. 2016). Bacterial metabolic activity is especially sensitive to the ultraviolet UV-B (280-320 nm) and UV-A (320-400 nm) range (Obernosterer et al. 1999). Naganuma et al. (1996) and Benner and Biddanda (1998) found decreased bioavailability of organic matter in bacteria exposed to UV radiation. The exposure of dissolved organic matter to solar radiation leads to the inhibition of bacterial growth and formation of substances which decrease the level of bacterial production (Joux et al. 2006; Zàncker et al. 2017).

The horizontal zonation of bacterial abundance is a wellknown global phenomenon reported from different water basins (Varela et al. 2003; Anas et al. 2021; Figueroa et al. 2021). The results of the present study carried out along the horizontal transect in the harbour channel in Ustka also indicated that bacterial abundance was highly variable between the sample sites of the studied water basin. The total number of bacteria over the longitudinal transect was the highest in freshwater (site 1), while it was much lower, but at similar level, at all other sites. Probably this variation in the number of bacteria along the horizontal profile of the harbour channel in Ustka may result from changing water salinity. A gradient of decreasing bacterial numbers with increasing salinity was noted in several water basins (Cunliffe et al. 2009; Lefort and Gasol 2013; Jacquemot et al. 2021) and that corresponds well with our results. According to Santos et al. (2011) in the Ria de Aveiro estuary, total bacterial number was lower in hydrodynamic zone (seawater zone), whereas it was higher in more stable zone (freshwater and brackish water zone). The relation between prokaryotic cell number and salinity in water ecosystems is negative because bacteria require more energy for the production of osmolytes and less for reproduction (Perliński et al. 2017). In addition to salinity, an important factor limiting the number of bacteria in the water in the central and ending part of the harbour channel (Table 4) was the accumulation of heavy metals and a relatively large accumulation of petroleum hydrocarbon pollutants. 
Similarly to the total bacteria number, the level of secondary production of bacteria varied between the zones of the studied harbour channel in Ustka. The secondary production of bacteria at the site located where the channel enters the sea was two to three times lower than at other sites. Also Varela et al. (2003) in the Ria de Ferrol (Galicia, NW Spain) noted that bacterial carbon production was higher in the inner part of the estuary than in the outer station. Such differences in the level of bacterial production in the horizontal profile may be explained by the results of the studies carried out by Dagg and Breed (2003) and Manini et al. (2004). These researchers point out that in addition to composition, availability and degradability of organic compounds, originating mainly from primary phytoplankton production, in the river estuaries such as the Ustka harbour channel the driving force for the secondary bacterial production is also the river inflow of organic matter, which influences the zone where the channel enters the sea as well, but to the least extent.

The results of the present study showed significant seasonal dynamics in the total number of bacteria inhabiting the port channel in Ustka showed. The maximum total number of neustonic and planktonic bacteria was recorded in summer and the minimum in autumn and winter. These findings are consistent with the results of the studies from the estuarine and marine waters (Varela et al. 2003; Mudryk and Skórczewski 2007; Dreshchinskii and Engel 2017; Figueroa et al. 2021) and freshwater basins (Kalwasińska and Donderski 2005; Kostrzewska-Szlakowska and Kiersztyn 2017; Krevš et al. 2019). According to these researchers, the main stimulator of bacterial growth in summer is the intensive development of phytoplankton, often in bloom form. These organisms release organic matter to water in the form of assimilates, which are an optimal food base generating intensive multiplication and thus an increase in the number of bacteria at this time of year (Kalwasińska and Donderski 2005; Antonowicz et al. 2015). Summer maxima of the total number of bacteria in the examined channel may also be the effect of relatively high temperatures at this time of year (Mudryk and Skórczewski 2007; Zdanowicz and Mudryk 2017; Krevš et al. 2019). According to Benner et al. (1995) and Cottrell and Kirchman (2000) temperature is a major abiotic factor that significantly influences the seasonal variation in bacterial abundance in aquatic ecosystems.

In the port channel in Ustka, the seasonal differences in the level of bacterial production were noted. In eutrophicated ecosystems, the growth rate of bacteria and their production are mainly regulated by temperature, because the availability of food substrates produced mainly by phytoplankton in these water bodies is still very high (Ameryk et al. 2005). According to Gertman et al. (2013) and Yucel (2017) temperature due to its influence on all chemical and biochemical processes in cells is a key parameter regulating bacterial growth and their productivity at a seasonal scale. Spring and summer maxima in the level of bacterial production recorded in the studied water basin may be the effect of relatively high temperature at this time of year. These data correspond to the results of the studies by Shiah et al. (2000), Mudryk and Skórczewski (2007), Zdanowicz and Mudryk (2017), and Yucel (2017) in marine and inland reservoirs.

\section{Conclusion}

Results presented in this study may add information in the explanation of the role of bacteriocenosis inhabiting the surface and subsurface layers of water of a polluted estuarine harbour channel in the degradation of organic matter and its flow through the microbial loop, which is a basic condition for maintaining homeostasis in any water body. However, although determination of bacterial numbers and their productivity in an estuary are methodically difficult processes, future studies need to be carried out as long-term investigations may provide reliable information on the role of bacteria as a key link in estuarine and marine biocenosis.

Acknowledgements We would like to thank the technical staff (Mr. Krzysztof Woźniak) of the Experimental Biology Department for help with laboratory work.

Author contributions All authors contributed to the study conception and design. Material preparation, data collection and analysis were performed by PP, MZ, ZJM and $€ K$. PP was responsible for field work and collection of research samples. ZJM, PP, ŁK drafted the manuscript which was critically reviewed by all of the authors.

Funding The work was performed with internal fund of the Institute.

Data availability All data generated or analysed during this study are included in this published article.

\section{Declarations}

Conflict of interest The authors declare that they have no conflict of interest.

Ethical approval The manuscript has not been submitted to any other journal and the work is original and not have been published elsewhere in any form or language (partially or in full). Results have been presented clearly, honestly, and without fabrication, falsification or inappropriate data manipulation.

Consent to participate All the co-authors have given their consent to participate as co-authors in the manuscript.

Consent for publication No third party data has been included without proper citation. Therefore, this is not applicable. 
Open Access This article is licensed under a Creative Commons Attribution 4.0 International License, which permits use, sharing, adaptation, distribution and reproduction in any medium or format, as long as you give appropriate credit to the original author(s) and the source, provide a link to the Creative Commons licence, and indicate if changes were made. The images or other third party material in this article are included in the article's Creative Commons licence, unless indicated otherwise in a credit line to the material. If material is not included in the article's Creative Commons licence and your intended use is not permitted by statutory regulation or exceeds the permitted use, you will need to obtain permission directly from the copyright holder. To view a copy of this licence, visit http://creativecommons.org/licenses/by/4.0/.

\section{References}

Almeida MA, Cunha MA, Alcântara F (2001) Factors influencing bacterial production in a shallow estuarine system. Microb Ecol 42:416-426

Ameryk A, Podgorska B, Witek Z (2005) The dependence between bacterial production and environmental conditions in the Gulf of Gdansk. Oceanologia 47:27-45

Anas A, Tharakan EMB, Jasmin C, Chandran C, Vipindas PV, Narayanan S, Jaleel KUA (2021) Microbial community shifts along an estuarine to open ocean continuum. Reg Stud Mar Sci 41:101587

Antonowicz JP, Kozak A (2020) Phytoneuston and chemical composition of surface microlayer of urban water bodies. Water 12:1904

Antonowicz J, Mudryk ZJ, Zdanowicz M (2015) A relationship between accumulation of heavy metals and microbiological parameters in the surface microlayer and subsurface water of a coastal Baltic Lake. Hydrobiologia 762:65-80

Antonowicz J, Mudryk ZJ, Perliński P, Kubiak J (2017a) Measurement of heavy metal concentrations and microbiological parameters in the surface microlayer of a downtown pond. Ecohydrol Hydrobiol 17:283-296

Antonowicz J, Grobela M, Opalińska M, Motała R (2017b) Heavy metals in beach deposits, bottom sediments of a Baltic fishing port and surface water. Baltic Coast Zone 21:211-224

Astrahan P, Herut B, Payton A, Rahav E (2016) The impact of dry atmospheric deposition on the sea-surface microlayer in the SE Mediterranean Sea: an experimental approach. Front Mar Sci 3:222. https://doi.org/10.3389/fmars.2016.00222

Azevedo JSN, Ramos I, Araújo S, Oliveira CS, Correia A, Henriques IS (2012) Spatial and temporal analysis of estuarine bacterioneuston and bacterioplankton using culture-dependent and culture-independent methodologies. Antonie Van Leeuw J Microb 101:819-835

Benner R, Biddanda B (1998) Photochemical transformation of surface and deep marine dissolved organic matter: effects on bacterial growth. Limnol Oceanogr 43:1373-1378

Benner R, Opsahl S, Chin-Leo G, Richey JE, Forsberg BR (1995) Bacterial carbon metabolism in the Amazon River system. Limnol Oceanogr 40:1262-1270

Chance RJ, Hamilton JF, Carpenter LJ, Hackenberg SC, Andrews SJ, Wilson TW (2018) Water-soluble organic composition of the Arctic Sea surface microlayer and association with ice Nucleation ability. Environ Sci Technol 52:1817-1826

Christowa C, Luks K, Christowa-Dobrowolska M, Szulc M, KiełbStańczuk M, Podruczna B, Kasperek S, Hącia E (2007) The development strategy of the sea port in Ustka by 2021. Business Mobility International Private Limited Company, Słupsk, pp 19-29

Chróst RJ, Overback J, Wcisło R (1988) Evaluation of the $\left[{ }^{3} \mathrm{H}\right]$ thymidyne method for estimating bacterial growth rates and production lake water. Re-examination and methodological comments. Acta Microbiol Pol 37:95-112

Chróst RJ, Koton M, Siuda W (2000) Bacterial secondary production and bacterial biomass in four Mazurian Lakes of differing trophic status. Pol J Environ Stud 9:255-266

Cottrell MT, Kirchman DL (2000) Community composition of marine bacterioplankton determined by $16 \mathrm{~S}$ rRNA gene clone libraries and fluorescence in situ hybridization. Appl Environ Microbiol 66:5116-5122

Cunliffe M, Whiteley AS, Newbold L, Oliver A, Schäfer H, Murrell JC (2009) Comparison of bacterioneuston and bacterioplancton dynamics during a phytoplankton bloom in a fjord mesocosm. Appl Environ Microb 75:7173-7181

Cunliffe M, Upstill-Goddard RC, Murrell JC (2011) Microbiology of aquatic surface microlayers. FEMS Microbiol Rev 35:233-246

Cunliffe M, Engel A, Frka S, Gašparovic B, Guitart C, Murrell C, Salter M, Stolle C, Upstill-Goddard R, Wurl O (2013) Sea surface microlayers: a unified physicochemical and biological perspective of the air-ocean interface. Prog Oceanogr 109:104-116

Dagg MJ, Breed GA (2003) Biological effects of Mississippi River nitrogen on the northern gulf of Mexico-a review and synthesis. J Mar Syst 43:133-152

Dreshchinskii A, Engel A (2017) Seasonal variations of the sea surface microlayer at the Boknis Eck Times Series Station (Baltic Sea). J Plankton Res 39:943-961

Engel A, Galgani L (2016) The organic sea surface microlayer in the upwelling region off Peru and implications for air-sea exchange processes. Biogeosciences 13:989-1007

Engel A, Bange HW, Cunliffe M, Burrows SM, Friedrichs G, Galgani L, Herrmann H, Hertkorn N, Johnson M, Liss PS, Quinn PK, Schartau M, Soloviev A, Stolle C, Upstill-Goddard RC, van Pinxteren M, Zäncker B (2017) The Ocean's vital skin: toward an integrated understanding of the sea surface microlayer. Front Mar Sci. https://doi.org/10.3389/fmars.2017.00165

Fan J, Li H, Chang Y, Wang X, Ming H, Su J, Li H (2018) Spatial analysis of bacterioneuston and bacterioplankton diversity in the north China Sea. Aquat Ecosyst Health. https://doi.org/10. 1080/14634988.2017.1400360

Figueroa D, Capo E, Lindh MV, Rowe OF, Paczkowska J, Pinhassi J, Andersson A (2021) Terrestrial dissolved organic matter inflow drives temporal dynamics of the bacterial community of a subarctic estuary (northern Baltic Sea). Environ Microbiol. https:// doi.org/10.1111/1462-2920.15597

Franklin MP, McDonald I, Bourne DG, Owens JP, Upstill-Goddard RC, Murrell JC (2005) Bacterial diversity in the bacterioneuston (sea surface microlayer): the bacterioneuston through the looking glass. Environ Microbiol 7:723-736

Fuhrman JA, Azam F (1982) Thymidine incorporation as a measure of heterotrophic bakterioplankton production in marine surface waters: evaluation and field results. Mar Biol 66:109-120

Galachyants AD, Tomberg IV, Sukhanova EV, Shtykova YR, Suslova MY, Zimens EA, Blinov VV, Sakirko MV, Domysheva VM, Belykh OI (2018) Bacterioneuston in Lake Baikal: abundance, spatial and temporal distribution. Int J Environ Res Public Health. https://doi.org/10.3390/ijerph15112587

Garrett WD (1965) Collection of slick-forming materials from the sea surface. Limnol Oceanogr 10:602-605

Gertman I, Goldman R, Ozer T, Zodiatis G (2013) Interannual changes in the thermohaline structure of the southeastern Mediterranean. In: Rapport du 40e Congrès du Commission Internationale pour l'Exploration Scientifique de la Mer Méditerranée, vol 40, p 211

Goosen NK, van Rijswijk P, Brockmann U (1995) Comparison of heterotrophic bacterial production rates in early spring in the turbid estuaries of the Scheldt and the Elbe. Hydrobiologia 311:31-42 
Grossman S, Dieckmann GS (1994) Bacterial standing stock, activity and carbon production during formation and growth of sea ice in the Weddell Sea, Antarctica. Appl Environ Microbial 60:2746-2753

Helm RR (2021) The mysterious ecosystem at the ocean's surface. PLoS Biol 19:e3001046

Hervas A, Casamayor EO (2008) High similarity between bacterioneuston and airborne bacterial community compositions in a high mountain lake area. FEMS Microb Ecol 67:219-228

Hyun JH, Kim KH (2003) Bacterial abundance and production during the unique spring phytoplankton bloom in the central Yellow Sea. Mar Ecol Prog Ser 252:77-88

Incera M, Cividanes SP, López J, Costas R (2003) Role of hydrodynamic conditions on quantity and biochemical composition of sediment organic matter in sandy intertidal sediments (NW Atlantic coast, Iberian Peninsula). Hydrobiologia 497:39-51

Jacquemot L, Kalenitchenko D, Matthes LC, Vigneron A, Mundy CJ, Tremblay JÉ, Lovejoy C (2021) Protist communities along freshwater-marine transition zones in Hudson Bay (Canada). Elem Sci Anthr 9:1

Joux F, Agogué H, Obernosterer I, Christine D, Reinthaler T, Herndl G, Lebaron P (2006) Microbial community structure in the sea surface microlayer at two contrasting coastal sites in the northwestern Mediterranean Sea. Aquat Microb Ecol 42:91-104

Kalwasińska A, Donderski W (2005) Neustonic versus planktonic bacteria in eutrophic lake. Pol J Ecol 53:571-577

Kostrzewska-Szlakowska I, Kiersztyn B (2017) Microbial biomass and enzymatic activity of the surface microlayer and subsurface water in two dystrophic lakes. Pol J Microbiol 66:75-84

Krevš A, Kučinskienė A, Manusadžianas L (2019) Long-term changes of water physicochemical conditions and benthic microbial processes in a small lake associated with land use in the catchment. Knowl Manag Aquat Ecosyst 420:47

Kurata N, Vella K, Hamilton B, Shivji M, Soloviev A, Matt S, Tartar A, Perrie W (2016) Surfactant-associated bacteria in the near-surface layer of the ocean. Sci Rep 6:19123

La Ferla R, Azzaro F, Azzaro M, Caruso G, Decembrini F, Leonardi M, Maimone G, Monticelli LS, Raffa F, Santinelli Ch, Zaccone R, Ribera d'Alcalà M (2005) Microbial contribution to carbon biogeochemistry in the Central Mediterranean Sea: variability of activities and biomass. J Mar Syst 57:146-166

Lee S, Fuhrman JA (1987) Relationships between biovolume and biomass of naturally derived marine bacterioplankton. Appl Environ Microbiol 53:1298-1303

Lefort T, Gasol JM (2013) Global-scale distributions of marine surface bacterioplankton groups along gradients of salinity, temperature, and chlorophyll: a meta-analysis of fluorescence in situ hybridization studiem. Aqat Microbial Ecol 70:111-130

Lemée R, Rochelle-Newall E, Van Wambeke F, Pizay M, Rainaldi M, Gattuso JP (2002) Seasonal variation of bacterial production, respiration and growth efficiency in the open NM Mediterranean Sea. Aquat Microbial Ecol 29:227-237

Ma YL, Lu W, Wan LL, Luo N (2015) Elucidation of fluoranthene degradative characteristics in a newly isolated Achromobacter xylosoxidans DN002. Appl Biochem Biotechnol 175:1294-1305

Manini E, Luna GM, Danovaro R (2004) Benthic bacterial response to variable estuarine water inputs. FEMS Microb Ecol 50:185-194

Mock T, Meiners KM, Giesenhagen HC (1997) Bacteria in sea ice and underlying brackish water at 54 $26^{\prime} 50^{\prime \prime} \mathrm{N}$ (Baltic Sea, Kiel Bight). Mar Ecol Prog Ser 158:23-40

Mudryk Z, Skórczewski P (2007) Abundance and productivity of estuarine neustonic and planktonic bacteria. Baltic Coast Zone $11: 25-40$

Naganuma T, Konishil S, Inouel T, Nakane T, Sukizaki S (1996) Photodegradation or photoalteration. Microbial assay of the effect of UV-B on dissolved organic matter. Mar Ecol Prog Ser 135:309-310

Nakajima R, Tsuchiya K, Nakatomi N, Yoshida T, Tada Y, Konno F, Toda T, Kuwahara VS, Hamasaki K, Othman BHR, Segaran TC, Effendy AWM (2013) Enrichment of microbial abundance in the sea-surface microlayer over a coral reef: implications for biogeochemical cycles in reef ecosystems. Mar Ecol Prog Ser 490:11-22

Obernosterer I, Reitner B, Herndl GJ (1999) Contrasting effects of solar radiation on dissolved organic matter and its bioavailability to marine bacterioplankton. Limnol Oceanogr 44:1645-1654

Obernosterer I, Catala P, Lami R, Caparros J, Ras J, Bricaud A, Dupuy C, van Wambeke F, Lebaron P (2008) Biochemical characteristics and bacterial community structure of the sea surface microlayer in the South Pacific Ocean. Biogeosciences 5:693-705

Perliński P, Mudryk ZJ, Antonowicz J (2017) Enzymatic activity in the surface microlayer and subsurface water in the harbour channel. Estuar Coast Shelf Sci 196:150-158

Perliński P (2015) Microbiological study of air-water and water-sediment interface in harbour channel in Ustka. Ph.D. thesis Pomeranian University in Słupsk, p 128

Ram ASP, Xavier M, Brune J, Jean-Pascal T, Chu VT, Raimbault P, Niggemann J, Sime-Ngando T (2018) Bacterial-viral interactions in the sea surface microlayer of a black carbon-dominated tropical coastal ecosystem (Halong Bay, Vietnam). Elem Sci Arthr 6:13

Sabbaghzadeh B, Upstill-Goddard RC, Beale R, Pereira R, Nightingale $\mathrm{PD}$ (2017) The Atlantic Ocean surface microlayer from $50^{\circ} \mathrm{N}$ to $50^{\circ} \mathrm{S}$ is ubiquitously enriched in surfactants at wind speeds up to $13 \mathrm{~ms}^{-1}$. Geophys Res Lett. https://doi.org/10.1002/2017GL0729 88

Santos L, Santos AL, Coelho FJ, Gomes NC, Dias JM, Cunha A, Almeida A (2011) Relation between bacterial activity in the surface microlayer and estuarine hydrodynamics. FEMS Microbiol Ecol 77:636-646

Santos L, Santos AL, Coelho FJRC, Gomes NCM, Dias JM, Cunha A, Almeida A (2013) Heterotrophic activities of neustonic and planktonic bacterial communities in an estuarine environment (Ria de Aveiro). J Plankton Res 36:230-242

Santos AL, Baptista I, Gomes NC, Henriques I, Almeida A, Correia A, Cunha A (2014) Contribution of chemical water properties to the differential responses of bacterioneuston and bacterioplankton to ultraviolet-B radiation. FEMS Microbiol Ecol 87:517-535

Shaharom S, Latif MT, Khan MF, Yusof SNM, Sulong NA, Wahid NBA, Uning R, Suratman S (2018) Surfactants in the sea surface microlayer, subsurface water and fine marine aerosols in different background coastal areas. Environ Sci Pollut Res 25:27074-27089

Shiah FK, Gong GC, Chen TY, Chen CC (2000) Temperature dependence of bacterial specific growth rates on the continental shelf of the East China Sea and its potential application in estimating bacterial production. Aquat Microb Ecol 22:155-162

Steinberg DK, Van Mooy BA, Buesseler KO (2008) Bacterial vs. zooplankton control of sinking particle flux in the ocean's twilight zone. Limnol Oceanogr 53:1327-1338

Stolle C, Nagel K, Labrenz M, Jürgens K (2009) Bacterial activity in the sea-surface microlayer: in situ investigations in the Baltic Sea and the influence of sampling devices. Aqat Microb Ecol 58:67-78

Stolle C, Nagel K, Labrenz M, Jürgens K (2010) Succession of the sea-surface miclolayer in the costal Baltic Sea under natural and experimentally induced low-wind conditions. Biogeosciences 7:2975-2988

Sun CC, Sperling M, Engel A (2018) Effect of wind speed on the size distribution of gel particles in the sea surface microlayer: insights from a wind-wave channel experiment. Biogeosciences $15: 3577-3589$ 
Tovar-Sánchez A, Arrieta JM, Duarte CM, Sañudo-Wilhelmy SA (2014) Spatial gradients in trace metal concentrations in the surface microlayer of the Mediterranean Sea. Front Mar Sci 1:79

Varela MV, Bode A, González N, Rodríguez C, Varela M (2003) Fate of organic matter in the Ría de Ferrol (Galicia, NW Spain): uptake by pelagic bacteria vs. particle sedimentation. Acta Oecol 24:S77-S86

Velji MJ, Albright J (1986) Microscopic enumeration of attached marine bacteria of seawater, marine sediment, fecal matter and kelp blade samples following pyrophosphate and ultrasound treatments. Can J Microbiol 32:121-126

Walczak M, Donderski W (2005) Bacterioneuston of water bodies. Post Mikrobiol 44:275-288

Westernhagen H, Landolt M, Kocan R, Fürstenberg G, Janssen D, Kremling K (1987) Toxicity of sea-surface microlayer: effects on herring and turbot embryos. Mar Environ Res 4:273-290

Wurl O, Obbard JP (2004) A review of pollutants in the sea-surface microlayer (SML): a unique habitat for marine organisms. Mar Pollut Bull 48:1016-1030

Wurl O, Ekau W, Landing WM, Zappa CJ (2017) Sea surface microlayer in a changing ocean-a perspective. Elem Sci Anthr 5:31. https://doi.org/10.1525/elementa.228

Xu X, Liu W, Tian S, Wang W, Qi Q, Jiang P, Gao X, Li F, Li H, Yu H (2018) Petroleum hydrocarbon-degrading bacteria for the remediation of oil pollution under aerobic conditions: a perspective analysis. Fron Microb 9:2885

Yucel N (2017) Seasonal and spatial variation of bacterial production and abundance in the northern Levantine Sea. Mediterr Mar Sci 18:97-106
Zäncker B, Bracher A, Röttgers R, Engel A (2017) Variations of the organic matter composition in sea surface microlayer: a comparison between open ocean, coastal and upwelling sites off the Peruvian coast. Front Microbiol 8:1-17

Zäncker B, Cunliffe M, Engel A (2021) Eukaryotic community composition in the sea surface microlayer across an east-west transect in the Mediterranean Sea. Biogeosciences 18:2107-2118

Zawadzka E (1996) Litho-morphodynamics in the vicinity of small ports of the Polish Central coast. In: Taussik J, Mitchel J (eds) Partnership of the Coastal Management. Samara Publ Limited, Cardigan, pp 353-360

Zdanowicz M, Mudryk ZJ (2017) Abundance, production and respiration of bacterioneuston and bacterioplankton in the coastal lake Dołgie Wielkie. Baltic Coast Zone 21:73-86

Zimmermann R, Meyer-Reil A (1974) A new method for fluorescence staing of bacterial populations an membrane filtres. Kiel Meer 30:24-27

Zwisler W, Selje N, Simon M (2003) Seasonal patterns of the bacterioplankton community composition in a large mesotrophic lake. Aqat Microb Ecol 31:211-225

Publisher's Note Springer Nature remains neutral with regard to jurisdictional claims in published maps and institutional affiliations. 